\title{
American Pediatric Society Presidential Address 2002: The Third Third
}

\author{
JUDITH G. HALL \\ University of British Columbia, Department of Pediatrics, British Columbia's Children's Hospital, \\ Vancouver, British Columbia, Canada V6H 3 V4.
}

Friends, colleagues, and guests. It has been an honor and a privilege to serve as the president of the American Pediatric Society (APS) during this last year. The APS is an honorable and honoring society. While reviewing many of the past APS presidential addresses and the wonderful book that was produced for the 100th anniversary, I found that presidential presentations fall into three categories: historical reflections, research presentations, and personal observations. My address encompasses some of all three, but my primary focus is on the need to regularly take stock and review the opportunities that lie ahead for APS.

\section{THE AMERICAN PEDIATRIC SOCIETY}

The APS was established at the turn of the last century, when pediatrics began to emerge as a discipline, having its own kinds of expertise, types of research, and set of issues. The APS is now in its 114th year (during World War II, two meetings were not held, so it is the 112th year of the academic meetings). As a society, the APS is, indeed, beginning to come of age. I shall say more about aging and stages in development later.

Clearly, the APS has become multifaceted. It functions as well as it does due to many factors, including the dedication of our staff; our council; the officers; and our many representatives to committees, programs, boards, and councils. The relationship APS has to other organizations, particularly the Society for Pediatric Research, enables it to do a wide variety of things, including the meeting, the journal, and the foundation. The APS has major input into the Pediatric Academic Meeting, which supports and reports the very best research related to child health in the world. As other specialty meetings have floundered, the pediatrics meetings have grown. APS has input into and our members contribute to our journal, Pediatric Research, which publishes some of the most important, cutting-edge work related to child health. Together with other groups, the APS makes awards, which bestow honor onto outstanding individuals, including the honor of becoming a member of the APS.

Received July 29, 2002; accepted August 27, 2002

Correspondence: Judith G. Hall, O.C., M.D., University of British Columbia, Department of Pediatrics, British Columbia Children's Hospital, Vancouver, BC Canada V6H 3V4; e-mail: Jhal@cw.bc.ca

DOI: 10.1203/01.PDR.0000052078.18329.D3
Part of being president is that you get to see how the system works. I soon realized that the secretary-treasurer is and has been absolutely essential to the APS, while the president has become almost superfluous, albeit a very great honor. It is interesting to realize that APS does not, at this time, function because of the engagement of its members, although they certainly do attend this meeting and hopefully read Pediatric Research. The APS appears to have an independent, selfsustaining, and almost ghostly presence. How much more exciting to be engaged, responding to the times, and truly making a difference!

Over the years, the APS has advocated for children in a variety of ways, particularly through or together with other organizations such as the American Board of Pediatrics, the American Academy of Pediatrics, the Ambulatory Pediatric Association, the Association of Medical School Pediatric Department Chairs, and the Association of Pediatric Program Directors. As these organizations and pediatric subspecialties developed, the position of the APS has been to support new developments but, consequently, losing some of its own authority and possibly identity.

Several years ago, Drs. Fred Battaglia and Dick Johnson developed APS work groups to emphasize areas that are part of our tradition, such as history, leadership, and advocacy. Out of that effort grew a position paper on academic excellence, educational seminars, and the project of the history of pediatric subspecialties. There is much of which to be justly proud, but so much more that could be done if we were to harness the unused expertise, experience, excellence, and energy of our members, both active and emeritus.

\section{PAUSE TO REFLECT}

The events of September 11th touched every person in North America in some way. The pain was shared by much of the rest of the world and, consequently, most people have taken time to reflect in a meaningful and different way during this last year. There is not only a concern about security and personal safety but also about the plight of children of the world, the psychological effects of terrorism on all of us; what needs to be and what can be different about our world. I suspect many of us have, also, individually reflected on our own lives, our own talents, what we contribute to the world, and what really matters to us.

It is timely to reflect about APS, its history, activities, effectiveness, and how it serves its members. Perhaps because 
I have been president, I personally have been struck by the fact that there are an enormous number of very talented people in the APS. Our meetings are vital and strong (particularly in comparison to those of the internists). Pediatric subspecialties do have a home in our Pediatrics Academic Societies meetings. The meeting continues to grow in both size and diversity. We have had enormously strong chairs of the Program Committees, and that has led to an ever more integrated and timely program. No matter what your specialty or age, you will find an exciting track to follow at the meeting. It may be a bit exhausting, but each meeting is sure to bring you up to date with the latest research in your field.

Perhaps it is my own age, but I began to think about the fact that as the very talented members of APS move from being top notch researchers, heads of divisions, chairs of departments, and deans of medical schools into less demanding positions, they may experience less stress but many of their talents and their hard-won wisdom are not being fully used. In general, as people age, their expertise, experience, and enthusiasm do not diminish - they usually increase - yet some of our more senior members may no longer be called upon to use those precious talents. Most of us are not out of date, we're not "fuddy duddies," nor do we necessarily want to be in charge or in control any longer. Our energy may have changed - the intensity and focus may have altered, but the light is still there, bright and strong, and we do want it to be used.

\section{APS NEW INITIATIVES}

The APS council has begun to examine ways to serve and use our senior members. The process has taken an interesting turn during this last year as council began to look at some of the unique roles that senior pediatricians can play. These roles include opportunities to serve as consultants, provide locums, develop new interests, and take part in a diverse set of new APS-related activities.

Sometimes, it is an external event like September 11th, a very personal experience within the family, and still other times, an anniversary or a birthday that causes one to stop and reflect. As the APS has been coming of age, the council is doing some self-reflection that may lead to changes in the organization in ways that will most appropriately serve its members.

There are a number of initiatives which the APS council is considering undertaking (Table 1). First is a survey of the membership to see what kinds of information the members would like to have and the type of activities the APS could undertake for them. Second, we plan to survey department heads as to the many types of arrangements that are made for and with senior pediatricians, to determine the full range of

Table 1. APS new initiatives

\footnotetext{
Survey: what APS can do for its members

What is the relationship of 65-year-olds to their academic department

What are some of the vocations and roles available

Fellowship for senior pediatricians

Consultant/locum positions needed

Position paper and/or summary of the survey findings
}

options and to try to bring some transparency to the best ways to serve both the departments and the senior pediatricians. Third is to introduce a fellowship designed for individuals who are over the age of 65 years to explore the options of various new vocations and ways that senior pediatricians can foster child health. This would represent a very different type of fellowship without the pressures of on-call or earning an income, but hopefully to prepare individuals for new directions and opportunities. Fourth is an initiative to develop a reference base, identifying APS members willing to serve as consultants or possibly to do locums for individuals who want to take well-earned sabbaticals. Those in the reference base would be the type of multitalented resource individuals who are so often needed in our modern academic pediatric world of subspecialties. Fifth is to develop a position paper or summary of our findings, the state of affairs, and the options. We want to hear from members about both your own experiences, particularly after age 65 , or professional experiences that others have had, to develop models of what to do and what not to do, as senior pediatricians plan ahead. We want to know your needs, in hopes that our society can serve its senior members and play more roles in caring for and caring about child and youth health. We want your input, please.

I entered the presidency of the APS with some rather unique perspectives given that I am a Canadian as well as an American, a woman in a field still dominated by men, and a clinical geneticist-pediatrician who began as an internist. Born and trained in the United States, I moved to Canada 20 years ago. Consequently, I sit outside the everyday workings of the U.S., but know them well, and have also been intimately aware of the everyday workings of pediatrics in Canada. It could be said that I am a true North American. I certainly have the perspective that we here in North America have, relatively speaking, excellent health care (in spite of all the problems upon which we continually focus). We are, generally speaking, secure and safe (in spite of September 11). We have a high standard of living (in spite of some major discrepancies), and we have high educational standards. We tend to complain regularly and consistently, but all it takes is one trip to a developing country to realize how incredibly fortunate we are. We need to ask ourselves what is our role in recognizing the anger and anguish that exist in developing countries which leads to events like September 11 th. What roles can we play in addressing the roots of violence and in channeling efforts that are constructive as we advocate for the health and well being of all children - the children of the world?

\section{OPPORTUNITIES FOR WOMEN}

Opportunities that exist for women to be professionals in North America are almost unique throughout most of the world, yet worldwide, there are many more opportunities to be developed for women. In preparation for this address, I read with great interest the 100-year history of APS, which Howard Pearson spearheaded. It is noteworthy that there was a lengthy discussion of the original "paternity" of the APS - who was the prime mover-because of course there were only male members at the beginning. 
I am a bit biased, but I believe women bring many very positive dimensions to professional life that are useful and important correctives, including their concern about the environment, their emphasis on mentoring and nurturing, and their traditional and important role in society to pass along values. Women have often brought a multidisciplinary, collaborative approach to their scientific work; they often use integrated, holistic, and more subjective solutions to research questions and problems. Their tendency is to be inclusive, to assure that everyone has been consulted and heard, and that all members of their team work together. The approaches are not necessarily better in all situations and certainly not unique to women, but they are complementary, and they can be corrective.

A woman first became an APS member 3 years after I was born. This suggests that the first 55 years - almost the first half of the history of APS - was dominated by men. Those early meetings had a very different flavor of collegiality, sport meets, conviviality, and grandeur - they were often congregations at famous spas and hotels.

Canadians were part of the APS from the beginning adding their excellent scientific observations and self-effacing world awareness (Table 2). The fifth president of APS, Alexander Blackader, was a Canadian, and over the 114 years there have been three or four other Canadian APS presidents, including myself (depending on who gets to claim Osler, and we all would like to- he was a remarkable man who charmed children and intuitively knew their diseases were different from those of adults). The first woman to become president of the APS was Hattie Alexander in 1965, and there have been five more women presidents, including myself - six in total - in 114 years. So, five Canadians and six women in 114 years. At least the women are ahead of the Canadians!

Of course, I raise the issue of gender because more and more women are selecting and being selected for medicine. Women are also increasingly choosing pediatrics as a specialty. We need to be sure that we in pediatrics, in APS, welcome them, that appropriate models are available to them, and that they are represented in positions of responsibility, power, and decision making (Table 3).

\section{THE THIRD THIRD}

I have mentioned my unique background and perspective to set the stage for sharing with you a rather personal experience, which occurred a few years ago. It was one of those experiences which caused me to stop and reflect. I received a birthday

Table 2. Previous APS presidents

$\begin{array}{ll}\text { Women } & \\ \text { Hattie Alexander } & 1965 \\ \text { Margaret H.D. Smith } & 1977 \\ \text { Mildred Stahlman } & 1985 \\ \text { Mary Ellen Avery } & 1991 \\ \text { Rebecca Buckley } & 2000 \\ \text { Canadians } & \\ \text { William Osler } & 1892 \\ \text { Alexander D. Blackader } & 1893 \\ \text { Alan Ross } & 1968 \\ \text { Charles Scriver } & 1995\end{array}$

Table 3. APS membership 2002

$\begin{array}{lr}\text { Total active members } & 957 \\ \text { Male } & 776 \\ \text { Female } & 181 \\ \text { Active members over } 65 & 170 \\ \text { Male } & 135 \\ \text { Female } & 35 \\ \text { Emeritus members } & 444 \\ \text { Male } & 384 \\ \text { Female } & 60 \\ \text { Honorary members } & 43 \\ \text { Male } & 37 \\ \text { Female } & 6 \\ \text { Total membership } & 1,444 \\ \text { Male } & 1,197 \\ \text { Female } & 247 \\ & \end{array}$

card - the type that says "the year you were born, so-and-so was a movie star, so-and-so was the World Series winner, such-and-such was the favorite song." Well that card also said that in the year I was born, my life expectancy was 59 years. Since it was my 59th birthday, I began to realize that I was now living on borrowed time - as you are, or may soon be. It was a bit of a shock. The borrowed time, that extended lifetime, those added years, are because of the advances in health care over the last 50-75 years, and the advances have been primarily in pediatric health care. Antibiotics were invented about the time I was born, and nutrition in North America has improved dramatically over the last 60 years (in spite of the introduction of fast food and soft drinks). Consequently, after reading an article in Newsweek several weeks later, which predicted our life-span, I learned I have the right to expect an extra third-a third that no previous generation has had or at least has had the right to expect.

Of course, what that means for those of us who undertook medical training is that during the first third of our lives, we are involved in establishing ourselves by getting trained, getting married, having our families and identifying who we are, and establishing our professional pathway (Table 4). The second third of our life will be or has been spent working as a professional. This is a wonderfully challenging and rewarding time, but also a time during which we support our children in their training and invest for our own retirement. Compared with the founders of APS whose predicted life expectancy was 47 years, we can now expect to live into our late 80 s or early $90 \mathrm{~s}$ - giving us a third third. I did a little math from the APS history book and determined that the founders actually lived to an average of 69 years of age. This must reflect that they, like we, were not only happy in their work but also that they, as we, survived childhood.

It has quietly crept up on us. Perhaps it was not possible until now to declare an extra third. Obviously, in the past, there have

Table 4. The three thirds

First third Education, socialization, establishment of career and family Second third Work, support children and parents, save for retirement

Third third How to prepare for it

How to use expertise, experience and wisdom

New options available

What is realistic 
been people living into their 90 s in fruitful and contributory ways. However, the expectation has not been that we would have decades after retirement.

Since most of us have or will have this extra 30 years, it means that we could have a whole new profession, avocation, or commitment if we so choose. At the turn of the last century, people retired at 65 because they were worn out. Because we now have the third third, we need to take the opportunity to reflect on it, to plan, and to choose. The previous simplistic approach to life after 60 , of staying with the same grindstone plugging away, or to "leaving it all behind" and going on cruises and to the golf course, simply do not reflect the opportunities of this new century. We need a realistic approach for this extra third of our life that we are being granted. Consequently, I am particularly eager to learn from some of you who are more senior than I what opportunities and options exist. I want the APS to play a significant role in defining what the many opportunities are for our members regarding how we can most happily and meaningfully live that extra third third of life. Goddess grant we avoid accidents, degenerative disease, and cancer, how we should use our hard-earned experience, our insights, and our wisdom to make the world a better place for children and youth, and through the process perhaps find our own fulfillment and generativity. This new third third is a very special opportunity not to be drifted into but rather to be embraced and sculpted.

\section{STAGES OF LIFE INFLUENCED BY GENETICS AND ENVIRONMENT}

There are a number of unique perspectives which I have wanted to share. The last one I will indulge is that of being a clinical geneticist interested in congenital anomalies. During the past year, I was privileged to have a sabbatical in Cambridge, England, and, as a side bar, I really believe in sabbaticals. The ancients who invented them were very wise. They recognized that it is human nature to have the need, every 7 years, to stop and reflect. Every 7 years every cell in your body, every molecule turns over. The opportunity to refocus, reflect on one's interests and skills, to take stock and to get rid of committees and unwanted responsibilities, and to have the chance to refocus is very special. In the business and busyness of North American Academic Pediatrics, we are led to feel we are indispensable, indestructible, and obligated, but the ancients were right that we need the chance to reflect and refocus. I have been fortunate and determined enough to have three sabbaticals.

During my last sabbatical, since my research interest is human congenital anomalies, I had planned to study human embryological development. With so much happening in developmental biology, I needed to catch up with understanding the genes which are involved in the developing human. I wanted to try to understand the hierarchical cascade of genes turning on and turning off in the orchestration of embryological development of the heart, the limb, the kidney, and so forth. There is not enough time to discuss these new developments in any depth, but what has become clear from molecular biology, developmental biology, and developmental genetics is that there are many different stages in the life cycle. In each stage, various types of growth or change occur in the developing and evolving human. Thresholds are passed to which one cannot return. Pathways are taken that establish permanent longlasting effects (Table 5).

As pediatricians, we are well aware of different stages in human development. We know that the care for prematures is different from the care for normal newborns. The health care for a young child is different from that for an older child. As pediatricians, you know that the diseases likely to strike and the types of therapy to be given differ at each of these stages. You are also aware that there exists growing understanding about the differences in metabolism, in energy sources, and in biochemical pathways at each of these stages and that there are time-specific, tissue-specific gene expressions.

To my mind, this is an extremely important perspective of which the rest of medicine needs to become aware. Not only is each stage of development different in terms of the biochemistry and genetic control, but also in terms of psychosocial development and psychological integration. The things that happen at the early stages of development have long-lasting effects on adult health. For example, it is now clear that having been intrauterine growth-retarded predisposes to hypertension, heart disease, and diabetes. However, what family practitioner or internist asks about your birth weight, about complications during your pregnancy, and about your mother's health during your pregnancy? None of the studies trying to find genes for diabetes or Alzheimer disease use the discriminators of intrauterine complications, birth weight, and maternal illness to clarify etiology. This is probably because most of us don't even know these things about ourselves.

The first president of APS, Abraham Jacobi, put it well in his 1889 inaugural address: "Pediatrics deals with the entire organism at the very period during which presents the most interesting features to the student of biology and medicine.... There is scarcely a tissue or an organ which behaves exactly alike at different periods of life." (1) I have become quite interested in the fetal origins of adult disease, a growing awareness that long-term health is integrally related to the early stages of development and that the genes we inherit are not deterministic, but rather our genotype encodes a potential range of phenotypes which provide us with a range of responses to the environment in which we grow and develop (2).

Table 5. Stages of human development

\begin{tabular}{ll}
\hline 1. & Preimplantation \\
2. & Embryo \\
3. & Early fetus \\
4. & Later fetus (viable) \\
5. & Newborn \\
6. & Infant \\
7. & Young child \\
8. & Older child \\
9. & Adolescent (gender differences) \\
10. & Adult (premenopause/postmenopause) \\
& A. Young \\
& B. Middle \\
11. & C. Midlife \\
12. & Old \\
\hline
\end{tabular}




\section{SUMMING UP}

There is not time to discuss these fascinating new scientific developments in detail, but I would like to pull together the themes and analogies of my presentation. I want to reinforce that everything from a society like APS to an individual like each of you goes through different stages in development. Each individual, each organization is unique and needs to be considered in its own special way, and yet there are predictable patterns that can be recognized if we take time to reflect and refocus. If the early stages are healthy (and those of APS have been), then a long life can be expected - and needs to be planned for. Just as APS and its members take on different and new tasks, so does the growing, living organism in different stages of life- using different energies, developing different pathways, and growing into new abilities. In addition to the fact that most of us will have an extra third of our lives which hopefully we can live fully, so we need to adjust our perspective about research, medicine, and our organizations to take into account different developmental stages. As an organization, we need to examine our maturation.

Reviewing history gives perspective. Unique events like birthdays or September 11th give us pause to stop, reflect, and plan appropriately for the future. It is my great hope that the APS, as it starts into its third century, will take the time to reflect upon and about the role that it could - and should - be playing as the most senior academic pediatric society in North America. What are we doing, what do we do for our members, what can one member's experience mean to another, what new roles should we be taking on, and how can the APS better serve you?

Thank you for the opportunity and honor to have served as your president.

\section{REFERENCES}

1. Pearson HA 1989 The Centennial History of the American Pediatric Society 1888 1988. A Century of Progress in Child Health. Yale University Print Service, New Haven, CT

2. Gilbert SF 2000 Developmental Biology. Sinauer Associates, Sunderland, MA 